\title{
КОМП’ЮТЕРНІ ЗАСОБИ ДЛЯ ПРОВЕДЕННЯ СКРИНІНГОВИХ МЕДИЧНИХ ДОСЛІДЖЕНЬ В РЕЖИМІ ВІДДАЛЕНОГО ДОСТУПУ
}

\author{
О. В. Бойко ${ }^{1}$, О. І. Дорош², О. Ю. Степанюк ${ }^{3}$ \\ Львівський національний медичний університет імені Д. Галицького ${ }^{1}$ \\ Національний університет “Києво-Могилянська академія» ${ }^{2}$ \\ Національний медичний університет імені О. О. Богомольця
}

\begin{abstract}
Methods and facilities for realization of screening medical researches with the use of modern internet-technologies are considered. Methodology and results of screening researches of style and quality of student's life from different countries on the Moodle platform base are shown.
\end{abstract}

Важливою задачею сучасної медицини є проведення профілактичних заходів з метою запобігання виникненню захворювань, виявлення груп ризику серед різних категорій населення, оцінювання стану популяційного здоров'я, стилю та якості життя різних вікових груп тощо.

Одним з інструментів для рішення цих задач є скринінгові дослідження. Для їх проведення використовують різноманітні методи та засоби: профілактичні огляди, анкетування, лабораторні та інструментальні дослідження тощо. Впровадження інформаційно-комп’ютерних технологій дозволяє суттєво прискорити процес проведення таких досліджень, збільшити кількість вибірки, оптимізувати процедуру збереження та обробки великих масивів даних. Сучасні Інтернет-технології дозволяють проводити скринінгові дослідження у режимі віддаленого доступу, що надає змогу порівнювати результати досліджень у різних регіонах та країнах. Для проведення скринінгових досліджень використовуються різні програмні засоби: наприклад, система комбінованого скринінгу вагітних жінок PRISKA (дослідження результатів УЗД та біохімічних аналізів з метою виявлення аномалій розвитку плода), система CATI (Computer Assisted Telephone Intervie), платформа MOODLE для проведення скринінгових досліджень на основі комп'ютерного опитування (анкетування) тощо. Програмний комплекс (платформа) Moodle є спеціалізованою системою управління навчанням (Learning management system - LMS). Moodle $\epsilon$ системою 3 відкритим кодом і являє собою програмне середовище, розроблене на основі технології $\mathrm{PHP}+\mathrm{MySQL}$, що працює під управлінням web-сервера Apache (Denver). Moodle-сервер може бути встановлений як на платформі Windows, так і на UNIX(Linux)-платформах. Система має модульну структуру і містить навчально-методичні матеріали, завдання, тести, комунікаційні засоби, засоби для обліку та статисти- ки. Програмний комплекс Moodle дозволяє проводити навчання та оцінювання знань медичного персоналу та студентів в on-line режимі. Результати контролю зберегаються у базі даних.

Для проведення скринінгових досліджень у режимі віддаленого доступу в рамках проекту транскордонного співробітництва в Політехнічному університеті м. Білосток (Польща) було розроблено систему 3 розширеною базою тестових питань на базі платформи Moodle. Питання в анкеті передбачають вибір відповідей з множини або введення текстової інформації у відповідні поля. Анкети адаптовано для користувачів з різних країн (Польща, Білорусія, Україна, Росія, Литва). Представникам кожної з країн надавався відповідний пароль доступу до системи. На рисунку 1 показано вікно вибору анкет.

На базі розробленої системи комп'ютерного анкетування були проведені скринінгові дослідження серед учнів та студентів різних країн з метою порівняльного аналізу якості їх життя та виявлення змін у стилі життя студентів протягом навчання в університеті.На кафедрі медичної інформатики Львівського медичного університету ім. Д. Галицького було проведено скринінгові дослідження «Стиль життя - Україна 2012-13». В анкетуванні також брали участь студенти інших українських вишів. Результати опитування були опрацьовані у середовищі електронних таблиць Excel з графічною візуалізацією результатів.

На рисунку 2 наведено приклад порівняльної оцінки результатів опитування серед студентів різних країн.

На основі проведених досліджень було, наприклад, встановлено, що соціально раціональний спосіб життя ведуть студенти з України та Білорусії, оскільки приблизно 90 \% 3 них ніколи не вживали наркотиків, близько $60 \%$ не палять. В той же час лише $62 \%$ респондентів із Польщі відчувають стрес, тоді як 91 \% українців та білорусів скаржаться на цей психоемоційний стан.

$\overline{\text { (c) О. В. Бойко, О. І. Дорош, О. Ю. Степанюк }}$ 
Puc. 1. Вікно вибору анкет для опитування студентів.
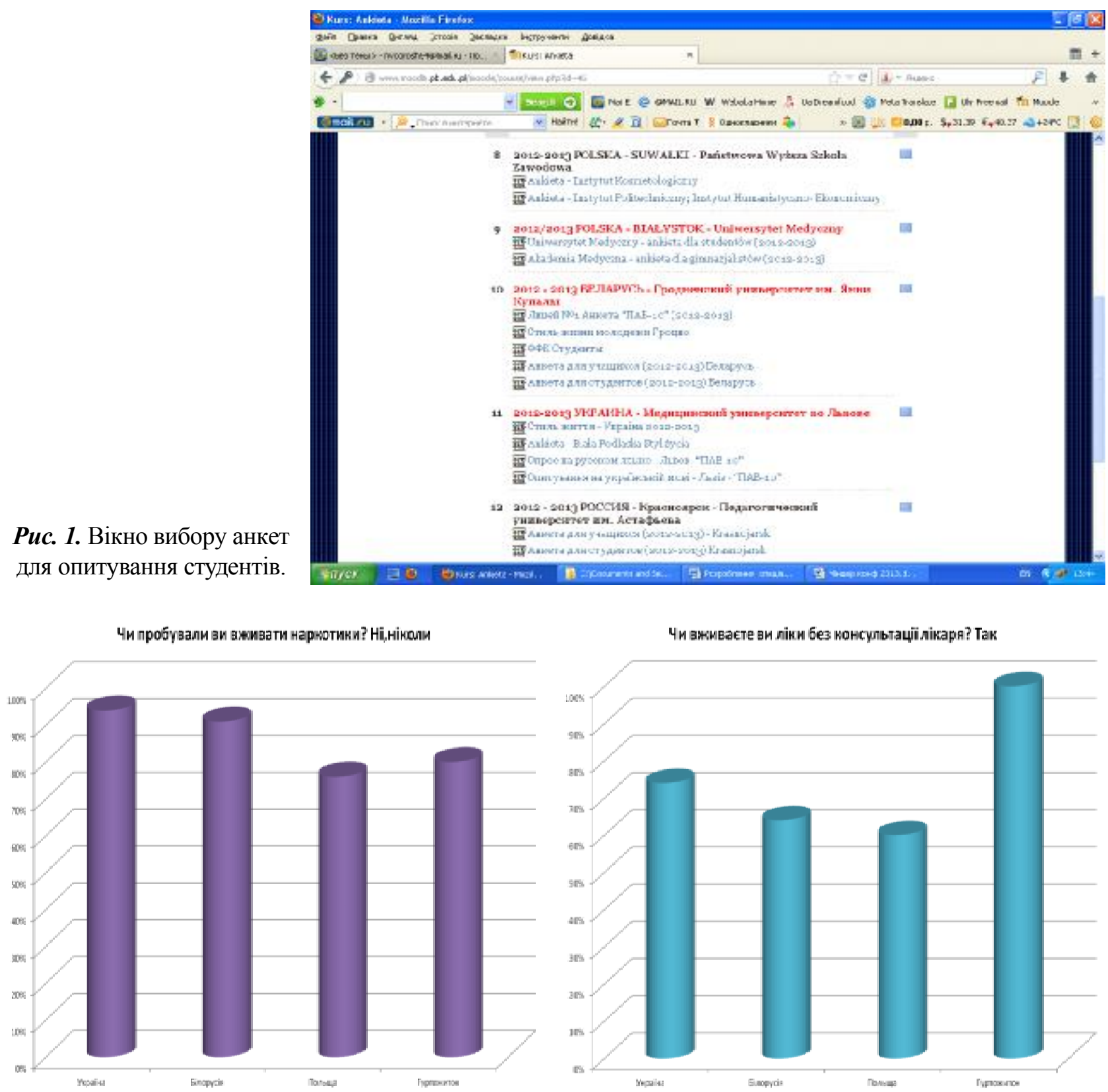

Puc. 2. Порівняльна характеристика результатів скринінгових досліджень.

Перспективним напрямком є розроблення інформаційно-аналітичних систем, які дозволять сумістити різні методи скринінгових досліджень, а також проводити комплексний аналіз фізіологічних та психологічних показників стану здоров'я різних груп населення (наприклад, система INANS). 